\title{
MASALAH PENYIDIK DALAM TINDAK PIDANA JASA KEUANGAN DI INDONESIA
}

\author{
Wahyu Wiriadinata ${ }^{1}$
}

\begin{abstract}
The objective of this article is to answer the question on the effectiveness of the investigators of the Financial Service Authority (Otoritas Jasa Keuangan or OJK) in combating financial crime in Indonesia. The question and problems arise because in the OJK Law there is a type investigator that has authority to investigate crimes which include several sectors, namely banking, capital markets, insurance, pension fund, financing institutions, and the other financial institutions. On the other side, previously, there was the other type of investigators that has authority to investigate, namely the Attorney General Office, Police, and the Corruption Eradication Commission (Komisi Pemberantasan Korupsi or KPK). This study uses two theoretical frameworks: 1) Aristotles's notion on the objective of law to achieving justice; 2) Hans Kelsen's Stuffen Theory. The method to write this article is juridical-normative, through studying the regulations (peraturan perundang-undangan), either incorporated in the statutes itself or in the legal literatures, particularly set of regulations on OJK. The result is the juridical analysis that manifested in the form or descriptive analysis. The conclusion of this study is there will be an overlapping between the investigators of OJK and the other investigators from the Attorney General Office, Police, and KPK, either in the investigation of general crime or special crime/corruption, regarding the effectiveness of the investigators of OJK must be proven in the future.
\end{abstract}

Keywords: Investigators, financial services, effectiveness, overlapping

\begin{abstract}
Abstrak
Tulisan ini, bertujuan untuk menjawab pertanyaan sampai sejauh mana efektivitas penyidik Otoritas Jasa Keuangan (OJK) dalam menanggulangi kejahatan jasa keuangan di Indonesia. Pertanyaan dan masalah ini muncul karena dalam Undang-Undang Otoritas jasa Keuangan ada Penyidik OJK yang mempunyai kewenangan penyidikan terhadap tindak pidana OJK yang mencakup sektor perbankan, pasar modal, perasuransian, dana pensiun, lembaga pembiayaan, dan lembaga jasa keuangan lainnya. Padahal sudah ada penyidik lain yang mempunyai kewenangan untuk menyidik, yaitu Kejaksaan, Kepolisian dan KPK. Kerangka teoritis bertolak dari pemikiran Aristoteles yang mengemukakan tentang tujuan hukum untuk mencapai keadilan juga stuffen theory dari Hans Kelsen. Metode penulisan adalah yuridis normatif,

\footnotetext{
${ }^{1}$ Penulis adalah Staf Pengajar pada Fakultas Hukum Universitas Pasundan. Alamat kontak: wahyuwiriadinata@yahoo.co.id.
} 
dengan mempelajari peraturan perundang-undangan, baik yang ada dalam undang-undang itu sendiri maupun yang ada dalam literatur/buku ilmu pengetahuan hukum, khususnya perundang-undangan yang berkaitan dengan Otoritas Jasa Keuangan. Hasilnya berupa aspek yuridis dituangkan dalam bentuk deskriptif analitis. Adapun kesimpulan dari tulisan ini adalah : Akan terjadi tumpang tindih antara penyidik OJK dengan Penyidik Jaksa, Polisi dan KPK, baik dalam penyidikan tindak pidana umum maupun khusus/korupsi, tentang efektivitas dari penyidik OJK harus dibuktikan di masa yang akan datang.

Kata kunci: penyidik, jasa keuangan, efektivitas, tumpang tindih

\section{Pendahuluan}

Dalam rangka membangun perekonomian nasional yang tumbuh dengan stabil dan berkelanjutan, menciptakan keseimbangan di semua sektor perekonomian, serta memberikan kesejahteraan secara adil kepada seluruh rakyat Indonesia maka program pembangunan ekonomi nasional harus diwujudkan dengan menyeluruh dan bisa menggerakkan kegiatan perekonomian nasional yang memiliki jangkauan yang luas dan menyentuh ke seluruh sektor nyata. Salah satu komponen penting dalam sistem perekonomian nasional dimaksud adalah sistem keuangan dan seluruh kegiatan yang menjalankan fungsi perantara bagi berbagai kegiatan produktif di dalam perekonomian nasional.

Globalisasi ekonomi telah menciptakan sistem keuangan yang kompleks, dinamis, dan saling terkait antar-subsektor keuangan baik dalam hal produk maupun kelembagaan. Adanya lembaga jasa keuangan yang memiliki hubungan kepemilikan di berbagai subsektor keuangan telah menambah kompleksitas transaksi dan interaksi antarlembaga jasa keuangan di dalam sistem keuangan.

Banyaknya permasalahan lintas sektoral di sektor jasa keuangan, yang meliputi tindakan moral hazard, belum optimalnya perlindungan konsumen jasa keuangan, dan terganggunya stabilitas sistem keuangan semakin mendorong diperlukannya pembentukan lembaga pengawasan di sektor jasa keuangan yang terintegrasi.

Oleh karena itu, perlu dilakukan penataan kembali struktur pengorganisasian dari lembaga-lembaga yang melaksanakan tugas pengaturan dan pengawasan di sektor jasa keuangan yang mencakup sektor perbankan, pasar modal, perasuransian, dana pensiun, lembaga pembiayaan, dan lembaga jasa keuangan lainnya, agar dapat dicapai mekanisme koordinasi yang lebih efektif di dalam menangani permasalahan yang timbul dalam sistem keuangan sehingga dapat lebih menjamin tercapainya stabilitas sistem keuangan. Pengaturan dan pengawasan terhadap keseluruhan kegiatan jasa keuangan tersebut harus dilakukan secara terintegrasi.

Otoritas Jasa Keuangan diperlukan agar keseluruhan kegiatan jasa keuangan di dalam sektor keuangan terselenggara secara teratur, adil, 
transparan, dan akuntabel, serta mampu mewujudkan sistem keuangan yang tumbuh secara berkelanjutan dan stabil, dan mampu melindungi kepentingan konsumen dan masyarakat. Dengan tujuan ini, OJK diharapkan dapat mendukung kepentingan sektor jasa keuangan nasional sehingga mampu meningkatkan daya saing nasional. Selain itu, OJK harus mampu menjaga kepentingan nasional, antara lain, meliputi sumber daya manusia, pengelolaan, pengendalian, dan kepemilikan di sektor jasa keuangan, dengan tetap mempertimbangkan aspek positif globalisasi.

Otoritas Jasa Keuangan yang mandiri/independen dilandaskan asas-asas :

1. Independensi, yakni independen dalam pengambilan keputusan dan pelaksanaan fungsi, tugas, dan wewenang OJK, dengan tetap sesuai peraturan perundang-undangan yang berlaku;

2. Kepastian hukum, yakni asas dalam negara hukum yang mengutamakan landasan peraturan perundang-undangan dan keadilan dalam setiap kebijakan penyelenggaraan Otoritas Jasa Keuangan;

3. Kepentingan umum, yakni asas yang membela dan melindungi kepentingan konsumen dan masyarakat serta memajukan kesejahteraan umum;

4. Keterbukaan, yakni asas yang membuka diri terhadap hak masyarakat untuk memperoleh informasi yang benar, jujur, dan tidak diskriminatif tentang penyelenggaraan Otoritas Jasa Keuangan, dengan tetap memperhatikan perlindungan atas hak asasi pribadi dan golongan, serta rahasia negara, termasuk rahasia sebagaimana ditetapkan dalam peraturan perundang-undangan;

5. Profesionalitas, yakni asas yang mengutamakan keahlian dalam pelaksanaan tugas dan wewenang Otoritas Jasa Keuangan, dengan tetap berlandaskan pada kode etik dan ketentuan peraturan perundangundangan;

6. Integritas, yakni asas yang berpegang teguh pada nilai-nilai moral dalam setiap tindakan dan keputusan yang diambil dalam penyelenggaraan Otoritas Jasa Keuangan; dan

7. Akuntabilitas, yakni asas yang menentukan bahwa setiap kegiatan dan hasil akhir dari setiap kegiatan penyelenggaraan Otoritas Jasa Keuangan harus dapat dipertanggungjawabkan kepada publik.

Di Indonesia peran jasa keuangan pernah mengalami masa yang dinilai tidak melindungi masyarakat pengguna jasa keuangan, malah merugikan masyarakat dan negara, sebagaimana yang terjadi pada kasus/perkara Bantuan Likuiditas Bank Indonesia (BLBI).

Kasus BLBI merupakan masalah yang cukup mengguncangkan kondisi perbankan dan perekonomian Indonesia yang berimbas ke masalah politik dan hukum. Dalam kasus BLBI ini yang berawal dari 1997 banyak melibatkan para pejabat tinggi dari mulai Presiden Soeharto, Menteri Perekonomian dan Perindustrian, Menteri Keuangan, Menteri Sekretaris Negara, Pejabat Tinggi Bank Indonesia termasuk Anggota DPR masa jabatan 1999-2004 yang menangani Bidang Ekonomi dan Keuangan. Kasus ini bermula pada Agustus 
1997 ketika pemerintahan rejim Soeharto melepas sistem kurs mengambang terkendali (free floating). Masyarakat panik lalu belanja dollar dalam jumlah yang sangat besar. Setelah dana pemerintah ditarik ke Bank Indonesia, tingkat suku bunga di pasar uang dan deposito melonjak drastis karena bank-bank berebut dan menguras dana masyarakat. Pada 1 September 1997 Bank Indonesia menurunkan suku bunga SBI sebanyak tiga kali, kemudian muncul isu di masyarakat mengenai beberapa bank besar yang mengalami kalah kliring dan rugi dalam transaksi valuta asing. Hal ini menimbulkan tingkat kepercayaan masyarakat terhadap bank nasional goyah, sehingga terjadi rush. Atas fenomena ini, pemerintah akan membantu bank sehat yang mengalami kesulitan likuiditas, sedangkan bank yang sakit dimerger atau dilikuidasi. Kebijakan yang berupa kredit ini dinamakan Bantuan Likuiditas Bank Indonesia (BLBI). Pada 1 November 1997 ada 16 bank yang dilikuidasi, pada tanggal 31 Desember 1997 Bank Indonesia mulai membuka dan mengucurkan aliran dana besar-besaran ke bank-bank yang saat itu mengalami masalah keuangan yang nilainya mencapai kurang lebih 600 triliun. BLBI senilai kurang lebih 600 triliun itu ternyata oleh bank penerima bantuan malah diselewengkan, sehingga menjadi masalah pidana, menjadi perkara tindak pidana korupsi yang penanganannya dilakukan oleh Kejaksaan Agung Republik Indonesia.

Ada beberapa perkara BLBI ini yang melibatkan Bank besar yang perkaranya telah diputus dan dinyatakan para pimpinan bank tersebut terbukti melakukan tindak pidana korupsi. Akan tetapi perkara yang lainnya yang melibatkan konglomerat kakap ternyata perkaranya oleh Kejaksaan Agung dihentikan penyidikannya.

Akan tetapi terhadap penghentian penyidikan tersebut, Masyarakat Anti Korupsi Indonesia mengajukan praperadilan. Pada tanggal 6 Mei 2008 Pengadilan Negeri Jakarta Selatan mengabulkan permohonan praperadilan Masyarakat Anti Korupsi Indonesia terhadap surat perintah penghentian penyidikan (SP3) yang dikeluarkan Kejaksaan Agung atas kasus Bantuan Likuiditas Bank Indonesia (BLBI) Syamsul Nursalim. Kejaksaan Agung langsung menyatakan banding. Persoalannya terus menjadi polemik di antara para aparat penegak hukum (Kejaksaan, Kepolisian dan KPK), pemerintah dan para politisi di Dewan Perwakilan Rakyat. Kondisi yang tidak menentu ini jelas merugikan masyarakat konsumen pengguna jasa keuangan (perbankan) dan negara.

Demikian pula kasus Bank Century berawal dari kegagalan bank tersebut dalam memenuhi prefund kliring (transaksi antar bank) di Bank Indonesia pada 13 November 2008, seperti yang diakui oleh manajemen bank tersebut. Dalam pengakuannya, Manajemen Bank Century menyampaikan bahwa bank tersebut hanya terlambat 15 menit saat harus memenuhi dana prefund kliring sebesar Rp. 5 miliar yang seharusnya ditransfer pada pukul 08.00 WIB. Sehingga manajemen Bank Century mengumumkan bahwa pihaknya mengalami kalah kliring karena tingginya intensitas transaksi dana masuk dan dana keluar nasabah sehubungan dengan ketatnya likuiditas saat ini. Pada saat yang bersamaan, Muliaman D Hadad, Deputi Gubernur Bank Indonesia, mengaku 
tidak tahu-menahu mengenai hal tersebut. Dia mengatakan semua bank, baik besar maupun kecil, saat ini dalam pengawasan BI agar persoalan likuiditas ini bisa dikendalikan secara baik. Pada 21 November 2008, akhirnya Gubernur Bank Indonesia Boediono mengumumkan bahwa BI melalui Komite Stabilitas Sistem Keuangan (KKSK) memutuskan pengambilalihan Bank Century oleh Lembaga Penjamin Simpanan (LPS).

Meskipun Bank Indonesia menyadari bahwa kondisi kesehatan Bank Century dalam keadaan buruk, LPS meminta nasabah tak perlu panik karena lembaga tersebut akan menjamin seluruh kebutuhan likuiditas Bank Century dengan alokasi dana sebesar Rp. 1 triliun.

Berdasarkan data LPS, suntikan dana yang telah dikucurkan oleh lembaga tersebut kepada Bank Century total dana yang dikucurkan adalah Rp. 6,77 triliun.

Bukti ketidak-beresan manajemen Bank Century dalam menjalankan operasionalnya semakin terlihat ketika ditetapkannya status tersangka kepada mantan Direktur Utama Bank Century, Hermanus Hasan Muslim pada 27 November 2008. berdasarkan pemeriksaan penyidik Polisi, Hermanus telah melanggar tindak pidana perbankan. Hermanus terbukti telah menjalankan permintaan dari tersangka sebelumnya yaitu Robert Tantular.

Kasus Bank Century ternyata tidak sekedar masalah internal, ternyata dugaan atas lemahnya pengawasan dan koordinasi antara Bank Indonesia dan Bapepam-LK terbukti dengan mencuatnya masalah penggelapan dana investasi PT Antaboga Sekuritas di Bank Century. Perusahaan yang berdiri sejak tahun 1989 ini diadukan para nasabah ke Badan Pengawas Pasar Modal dan Lembaga Keuangan (Bapepam-LK). Beberapa manajemen perusahaan itu diduga menggelapkan uang milik investor. Kerugian sementara yang diderita para investor adalah Rp. 233 miliar. Kerugian ini, menurut Polisi kemungkinan akan bertambah.

Kisruh di Antaboga berawal dari kasus yang terjadi di PT. Bank Century Tbk, ketika operasional Bank Century diambil alih oleh Lembaga Penjamin Simpanan (LPS), ratusan nasabah Antaboga mendatangi kantor perusahaan tersebut. Mereka ingin menarik dananya yang diinvestasikan di reksadana. Pasalnya, produk investasi yang diterbitkan Antaboga, dipasarkan oleh Bank Century. Nasabah Antaboga kebanyakan adalah nasabah Bank Century. Mereka diminta menandatangani sertifikat reksadana di kantor Bank Century.

Dengan adanya kasus Bank Century yang sekarang berubah nama menjadi Bank Mutiara telah ada pimpinan Bank Century yang dipidana, akan tetapi kasus yang lain yang kerugian negaranya lebih besar dan melibatkan para petinggi dan penguasa di Indonesia, kasusnya belum terselesaikan dengan tuntas.

Adapun kasus pencucian uang yang merugikan konsumen jasa keuangan di masyarakat antara lain kasus Dhana Widyatmika dijerat dengan Pasal 55 ayat 1, Pasal 3 dan 4 UU No. 8/2010 tentang Pencegahan dan Pemberantasan Tindak Pidana Pencucian Uang.

Dhana Widyatmika diduga memiliki berbagai usaha untuk melakukan pencucian uang, antara lain memiliki perusahaan PT. Mitra Modern Mobilindo 
(jual beli mobil), PT. Bangun Bumi Persada (real estate), PT. Trisula Artamega (perdagangan); memiliki beberapa kapling tanah senilai Rp. 4,5 miliar, minimarket dan peternakan ayam. Ditemukan dalam satu rekening terdapat aliran dana senilai Rp. 97 miliar. Dhana diduga memiliki kekayaan senilai Rp. 60 miliar.

Kasus Dhana Widyatmika ini sekarang sedang ditangani oleh penyidik Kejaksaan Agung RI, akan tetapi kasus lain yang terkait yang melibatkan para pejabat tinggi di Departemen Keuangan dan nilai pencucian uangnya lebih dari kasus Dhana, nampaknya belum disentuh oleh aparat penegak hukum.

Untuk menjawab, menyelesaikan dan mencegah kasus-kasus tersebut di atas tidak terulang kembali. Pemerintah dan negara telah mengambil langkahlangkah pencegahan, antara lain dengan diundangkannya Undang-Undang Nomor 21 Tahun 2011 tentang Otoritas Jasa Keuangan (OJK). Sebagai pelengkap atau menyempurnakan peraturan perundang-undangan yang mempunyai fungsi dan tujuan yang sama dengan undang-undang OJK yaitu undang-undang tentang Bank Indonesia. Dalam Undang-Undang Nomor 21 tahun 2011 tersebut secara khusus diberikan wewenang kepada penyidik OJK untuk melakukan penyidikan terhadap kejahatan OJK. Undang-undang tentang Bank Indonesia mempunyai fungsi dan tujuan antara lain melindungi kepentingan konsumen jasa keuangan di masyarakat, walaupun setelah sekian lama undang-undang tentang Bank Indonesia berlaku, perlindungan terhadap konsumen tetap lemah, dengan indikasi beberapa kasus seperti yang telah dibeberkan di atas.

Selain itu dengan lahirnya undang-undang tentang otoritas jasa keuangan, dimana otoritas jasa keuangan mempunyai fungsi juga tentang pengawasan terhadap perbankan, sedangkan dalam undang-undang Bank Indonesia Pasal 8 c: Untuk mencapai tujuan sebagaimana dimaksud dalam Pasal 7, Bank Indonesia mempunyai tugas sebagai berikut: c. mengatur dan mengawasi Bank. Dengan demikian terjadi tumpang tindih dalam pengawasan terhadap OJK khususnya di sektor Perbankan. Begitu pula tentang penyidik OJK dan menemukan problema yang sama di mana yang akan datang, sebab akan terjadi over lap dengan penyidik yang ada yaitu penyidik Kejaksaan, Kepolisian dan KPK.

Dari uraian tersebut di atas muncul pertanyaan yang perlu dilakukan pengkajian yaitu: Sejauh mana efektivitas dari penyidik OJK dalam menanggulangi kejahatan Jasa Keuangan di Indonesia.

Untuk mengurai pertanyaan di atas dan menjawab permasalahan yang telah dirumuskan, digunakan metode penelitian, yaitu penelitian hukum normatif/yuridis normatif, data yang diperoleh dianalisis secara deskriptif kualitatif. Analisis deskriptif kualitatif yaitu metode analisis data yang mengelompokkan dan menyeleksi data primer berupa undang-undang, kemudian dihubungkan dengan teori-teori, asas-asas, dan kaidah-kaidah hukum yang diperoleh dari studi kepustakaan sehingga diperoleh jawaban atas permasalahan yang dirumuskan.

Adapun guna tulisan ini ialah mudah-mudahan berguna bagi dunia ilmu pengetahuan hukum pada khususnya dan ilmu pengetahuan pada umumnya. 


\section{Landasan Pemikiran}

Aliran hukum alam didasari oleh pemikiran filosofis dari Aristoteles, dijelaskan bahwa pengertian adil menurut undang-undang dan adil menurut alam. Hukum alam berlaku di semua ruang dan sifatnya tidak tertulis. Lebih lanjut ditegaskan hubungan antara hukum alam dengan hukum positif. Aristoteles mengemukakan bahwa derajat hukum alam itu lebih tinggi dibandingkan hukum positif. Hukum alam itu melengkapi kekurangankekurangan yang dialami oleh hukum positif. Melengkapi kekurangankekurangan yang dialami oleh hukum positif. Hukum alam membawa kelayakan, melunakkan satu ketentuan umum yang terdapat dalam setiap peraturan perundang-undangan dengan memperhitungkan keadaan-keadaan tertentu dari tiap-tiap permasalahan. Namun demikian tidak berarti bahwa adil menurut kepatutan adalah tidak adil menurut undang-undang, akan tetapi kepatutan memberikan kesempurnaan. ${ }^{2}$

Pasca Aristoteles pemikiran tentang hukum alam atau hukum kodrat berkembang lebih jauh. Thomas Aquinas adalah salah satu pemikir hukum alam pasca Aristoteles yang pemikirannya lahir pada abad pertengahan yang cukup besar pengaruhnya terutama di kalangan kaum gereja Katholik bahkan sampai abad ke 21 ini, hal tersebut terlihat pada pembaharuan filsafatnya oleh pakar-pakar hukum khususnya yang beragama Katholik yang disebut aliran Neo-Thomistis. Berbeda dengan pandangan M.T. Cicero, Thomas Aquinas sebenarnya membedakan antara enam macam hukum, yaitu : hukum abadi (lex aeterna), hukum kodrat (lex naturalis), hukum manusia (lex humana), hukum Ilahi (lex devina), hukum yang diberikan oleh gereja kepada kaum beriman, kristiani (lex ecclesiastica), dan hukum nafsu, dorongan nafsu-nafsu dalam diri kita yang merangsang kita untuk berdoa (lex concupiscential). Pada abad pertengahan tersebut hukum alam dicirikan dengan bersumberkan dari rasio Tuhan.

Selanjutnya hukum alam dalam keragaman dan manifestasinya terlihat pada jaman Aufklarung (pencerahan), Thomas Hobbes mengartikan hukum alam sebagai susunan aturan-aturan yang harus dipakai sebagai pedoman bagi kemajuan seseorang menurut cita-cita rasionalnya, jika ia dapat mengetahui dengan sempurna semua keadaan yang meliputinya dan sama sekali tidak tergoncangkan oleh perasaan-perasaan yang mendadak dan prasangkaprasangka. Karena itu menurut anggapan sebagian besar manusia benar-benar bertindak demikian, maka aturan-aturan hukum alam secara hipotetis menetapkan syarat-syarat sebagai dasar yang memungkinkan tingkah laku manusia yang pokok untuk mendirikan suatu pemerintah yang kokoh. Aturanaturan tersebut bukanlah menentukan adat nilai, melainkan menetapkan secara sebab-akibat dan ajaran-ajaran hukum dan moral. Selanjutnya Thommas Hobbes berpendapat bahwa hukum alam fundamentil, yang pertama ialah mencari damai dan mengikutinya, manusia diperintahkan berusaha memperoleh damai dan keadilan, sejalan dengan alam pikiran Aristoeles.

\footnotetext{
${ }^{2}$ Roscoe Pound, "Pengantar Filsafat Hukum”, (Jakarta: Bharata, 1972), hal. 14.
} 
Akan halnya pemikiran dari aliran hukum positif/recht positivisme. Aliran positifisme ini sangat mengagungkan hukum tertulis. Aliran ini beranggapan bahwa tidak ada norma hukum di luar hukum positif, semua persoalan dalam masyarakat diatur dalam hukum tertulis. ${ }^{3}$

Tokoh yang paling berpengaruh dari aliran ini adalah Hans Kelsen. Menurutnya teori hukum murni adalah hukum positif. Ini merupakan teori tentang hukum positif umum, bukan penafsiran tentang norma hukum nasional atau internasional tertentu, namun ia menyajikan teori penafsiran. Pandangan Kelsen tentang hukum, sangat mencerminkan ciri positivisnya. Kelsen melihat hukum positif sebagai satu-satunya hukum, dan hukum harus benar-benar dipisahkan dari segala pengaruh anasir-anasir non hukum, seperti moral, politis, ekonomis, sosiologis, dan sebagainya. Kelsen selain dikenal sebagai pencetus teori hukum murni tapi berjasa mengembangkan teori jenjang (stuffen theory) yang semula dikemukakan oleh Adolf Merkl. Teori ini melihat hukum sebagai suatu sistem yang terdiri dari susunan norma berbentuk piramida. Norma yang lebih rendah memperoleh kekuatannya dari yang lebih tinggi. Semakin tinggi suatu norma semakin abstrak sifatnya, sebaliknya semakin rendah kedudukannya semakin konkrit norma tersebut. Norma yang paling tinggi di sebut oleh Kelsen dengan Grundnorm atau norma dasar. Pandangan semacam ini sudah tidak relevan lagi dalam masa modern kini. Tak mungkin kita menjadikan hukum sebagai sesuatu "benda otonom" yang berdiri terlepas sama sekali dari pengaruh ekonomi, politik, sosial dan budaya. Hukum tidak berada dalam ruangan hampa, tapi dia selalu berinteraksi dengan lingkungan sekelilingnya lebih-lebih di abad globalisasi ini. Demikianlah dalam UndangUndang OJK yang mengatur tersendiri tentang penyidikan yaitu dengan membentuk dan memberi kewenangan penyidikan terhadap tindak pidana OJK kepada penyidik tersendiri di luar penyidik yang telah ada sebelumnya, yaitu Jaksa, Polisi dan KPK dilakukan dengan maksud untuk adanya keseimbangan antara tujuan hukum untuk mencapai keadilan dan tujuan hukum untuk mencapai kepastian hukum.

\section{Pembahasan}

Dari landasan pemikiran di atas, maka kita dapat mengambil satu makna, sesungguhnya hukum itu terbentuk tidak lain adalah untuk menciptakan keadilan di samping adanya kepastian hukum. Tentang hukum yang bertujuan mencapai keadilan di masyarakat itu dilukiskan oleh Muchtar Kusumaatmadja dalam definisi hukumnya :

Hukum adalah keseluruhan asas dan kaidah yang mengatur pergaulan hidup manusia dalam masyarakat yang bertujuan untuk memelihara ketertiban dan mencapai keadilan, juga meliputi lembaga

3 Roelan Saleh, "Mengadili Sebagai Pergaulan Kemanusiaan", (Jakarta: Aksara Baru, 1983), hal. 77. 
serta proses yang mewujudkan berlakunya kaidah tersebut sebagai kenyataan di masyarakat. ${ }^{4}$

Dari definisi di atas Muchtar Kusumaatmadja menggaris bawahi bahwa sebelum tercapainya keadilan harus diciptakan dulu ketertiban di masyarakat, tidak mungkin ada keadilan kalau masyarakat tidak tertib. Artinya masyarakat harus mentaati hukum, baik hukum materil maupun hukum formil. Yang dimaksud dengan ketertiban di sini termasuk ketertiban dalam proses peradilan. Mulai penyidikan, pra-penuntutan, penuntutan, persidangan dan eksekusi. Termasuk di dalamnya proses dan penyelesaian perkara tindak pidana Otoritas Jasa Keuangan.

Tentang penyidikan, Pasal 1 butir 1 KUHAP menyebutkan, penyidik adalah pejabat polisi negara Republik Indonesia atau pejabat pegawai Negeri Sipil tertentu yang diberi wewenang khusus oleh undang-undang untuk melakukan penyidikan.

Pengangkatan untuk menjabat jabatan sebagai penyidik Polisi adalah berdasarkan penunjukan oleh Kepala Kepolisian RI (Kapolri).

Wewenang untuk menunjuk penyidik tersebut dapat dilimpahkan oleh Kapolri kepada Pejabat Kepolisian Negara RI. Sedangkan penyidik yang dijabat oleh Pegawai Negeri Sipil, pengangkatannya dilakukan oleh Menteri atas usul Departemen yang membawahi Pegawai Negeri Sipil tersebut. Mentri sebelum melaksanakan pengangkatan terlebih dahulu mendengarkan pertimbangan Jaksa Agung dan Kepala Kepolisian RI. Dan wewenang pengangkatan itu dapat dilimpahkan oleh Menteri Kepada Pejabat yang ditunjuknya. (Pasal 2 (6) PPRI No. 27/1983).

Pengangkatan seseorang menjadi penyidik pembantu, yang berasal dari kepolisian diangkat oleh Kepala Kepolisian RI atas usul dari komandan atau pimpinan kesatuannya masing-masing. Sedangkan pengangkatan Penyidik Pembantu yang berasal dari Pegawai Negeri Sipil dapat dilimpahkan kepada pejabat Kepolisian Negara RI.

(1) Penyidikan adalah tindakan selama pemeriksaan pendahuluan untuk mencari bukti-bukti tentang tindak pidana;

(2) Penyidikan dilakukan oleh:

a. Penyidik yang dijabat oleh pejabat Kepolisian Negara yang berpangkat sekurang-kurangnya Pembantu Letnan Dua;

b. Pembantu penyidik yang dijabat oleh pejabat Kepolisian Negara, yang berpangkat Sersan Dua sampai dengan Sersan Mayor dan anggotaanggota kepolisian khusus yang atas usul Komandan atau Kepala Jawatan Instansi Sipil pemerintah diangkat oleh Kapolri.

\footnotetext{
${ }^{4}$ P. Sitorus, "Pengantar Ilmu Hukum (Dilengkapi Tanya Jawab)", (Bandung: Pasundan Law Faculty, Alumnus Press, 1998), hal. 94.
} 
Yang dimaksud dengan Polisi Khusus, adalah pejabat-pejabat dari instansi/jawatan sipil tertentu yang diberi kewenangan Kepolisian khusus oleh undang-undang.

Selain itu ada juga penyidik tindak pidana tertentu, seperti penyidik tindak pidana tertentu/khusus yaitu penyidik Jaksa dan KPK yang melakukan penyidikan terhadap tindak pidana khusus korupsi.

Demikianlah Undang-undang Otoritas Jasa Keuangan yang mengatur tentang acara sendiri khususnya perihal penyidikan. Hal ini akan menimbulkan pertanyaan akankah terjadi penyidikan oleh penyidik OJK di dalam tindak pidana yang sama, dimana hak dan kewenangan penyidikan pada tindak pidana OJK dipunyai juga oleh penyidik lain yang telah ada. Keadaan ini nampaknya akan tidak selaras dengan integrated criminal justice system. Integrated criminal justice system mempunyai pengertian adanya keterpaduan penyidik bidang tindak pidana. Salah satu pilar dari sistem penanganan terpadu, adalah harus adanya koordinasi dari para penyidik. ${ }^{5}$

Dengan adanya penyidik Otoritas Jasa Keuangan, hal ini akan menimbulkan rebutan perkara dalam penyidikan tindak pidana OJK dan akan terjadi tumpang tindih kewenangan yang berujung kepada adanya nebis in idem.

Otoritas Jasa Keuangan (OJK) adalah lembaga yang mandiri dan independen serta bebas dari campur tangan pihak lain, yang mempunyai fungsi, tugas dan wewenang pengaturan, pengawasan, pemeriksaan, dan penyidikan di sektor perbankan, pasar modal, pengasuransian, dana pensiun, lembaga pembayaran dan lembaga keuangan lainnya. Dengan demikian termasuk penyidikan terhadap tindak pidana korupsi, perdagangan obat bius, perdagangan senjata dan manusia, penyelundupan, kejahatan di bidang perpajakan, pasar modal dan kejahatan di industri asuransi. Itu dapat disidik oleh penyidik OJK apabila terindikasi adanya kejahatan.

Dengan demikian penyidik OJK mempunyai kewenangan yang besar selain berwenang melakukan penyidikan yang tidak dipunyai oleh penyidik lain.

Dalam hal penyidikan terhadap tindak pidana jasa keuangan undangundang OJK mengaturnya dalam Pasal 49 yang berbunyi:

(1) Selain Pejabat Penyidik Kepolisian Negara Republik Indonesia, Pejabat Pegawai Negeri Sipil tertentu yang lingkup tugas dan tanggung jawabnya yang meliputi pengawasan sektor jasa keuangan di lingkungan OJK, diberi wewenang khusus sebagai penyidik sebagaimana dimaksud dalam Kitab Undang-Undang Hukum Acara Pidana.

(2) Pegawai negeri sebagaimana dimaksud dalam Pasal 27 ayat (2) dapat diangkat menjadi Penyidik Pegawai Negeri Sipil sebagaimana dimaksud pada ayat (1).

\footnotetext{
5 Barda Nawawi Arief, "Bunga Rampai Kebijakan Hukum Pidana", Cetakan Kesatu, (Bandung: Penerbit PT. Citra Aditya Bakti, 1996), hal. 61.
} 
(3) Penyidik Pegawai Negeri Sipil sebagaimana dimaksud pada ayat (1) berwenang:

a. menerima laporan, pemberitahuan, atau pengaduan dari seseorang tentang adanya tindak pidana di sektor jasa keuangan;

b. melakukan penelitian atas kebenaran laporan atau keterangan berkenaan dengan tindak pidana di sektor jasa keuangan;

c. melakukan penelitian terhadap Setiap Orang yang diduga melakukan atau terlibat dalam tindak pidana di sektor jasa keuangan;

d. memanggil, memeriksa, serta meminta keterangan dan barang bukti dari Setiap Orang yang disangka melakukan, atau sebagai saksi dalam tindak pidana di sektor jasa keuangan;

e. melakukan pemeriksaan atas pembukuan, catatan, dan dokumen lain berkenaan dengan tindak pidana di sektor jasa keuangan;

f. melakukan penggeledahan di setiap tempat tertentu yang diduga terdapat setiap barang bukti pembukuan, pencatatan, dan dokumen lain serta melakukan penyitaan terhadap barang yang dapat dijadikan bahan bukti dalam perkara tindak pidana di sektor jasa keuangan;

g. meminta data, dokumen, atau alat bukti lain, baik cetak maupun elektronik kepada penyelenggara jasa telekomunikasi;

h. dalam keadaan tertentu meminta kepada pejabat yang berwenang untuk melakukan pencegahan terhadap orang yang diduga telah melakukan tindak pidana di sektor jasa keuangan sesuai dengan ketentuan peraturan perundang-undangan;

$i$. meminta bantuan aparat penegak hukum lain;

j. $\quad$ meminta keterangan dari bank tentang keadaan keuangan pihak yang diduga melakukan atau terlibat dalam pelanggaran terhadap peraturan perundang-undangan di sektor jasa keuangan;

k. memblokir rekening pada bank atau lembaga keuangan lain dari pihak yang diduga melakukan atau terlibat dalam tindak pidana di sektor jasa keuangan;

l. meminta bantuan ahli dalam rangka pelaksanaan tugas penyidikan tindak pidana di sektor jasa keuangan; dan

m. menyatakan saat dimulai dan dihentikannya penyidikan.

Penyidik sebagaimana dimaksud dalam Pasal 49 menyampaikan hasil penyidikan kepada Jaksa untuk dilakukan penuntutan dan Jaksa wajib menindaklanjuti dan memutuskan tindak lanjut hasil penyidikan sesuai kewenangannya paling lama 90 (sembilan puluh) hari sejak diterimanya hasil penyidikan sebagaimana dimaksud pada ayat (1).

Tentang kewenangan penyidikan yang dipunyai oleh penyidik OJK ini, seperti penyidikan terhadap semua tindak pidana yang menyangkut jasa keuangan seperti diatur dalam sektor perbankan, pasar modal, perasuransian, dana pensiun, lembaga pembiayaan. Sementara terhadap tindak pidana 
perbankan telah ada penyidik sebelumnya yaitu pejabat Polisi Negara, Jaksa dan KPK.

Polisi sebagai penyidik tindak pidana - perbankan - diatur dalam Undang-Undang Nomor 8 Tahun 1981 tentang KUHAP Pasal 6 ayat (1) a. Penyidik adalah Polisi Negara Republik Indonesia, selain itu Polisi sebagai penyidik diatur pula dalam Undang-Undang Nomor 2 Tahun 2002 tentang Kepolisian RI Pasal 14 ayat (1) a:

Melaksanakan penyelidikan dan penyidikan terhadap semua tindak pidana sesuai dengan hukum acara pidana dan peraturan perundangundangan lainnya.

Dengan demikian Polisi sebagai penyidik termasuk penyidik mempunyai hak dan kewenangan untuk melakukan penyidikan terhadap semua tindak pidana, termasuk tindak pidana di sektor jasa keuangan (Perbankan dan lainlain).

Begitu juga Kejaksaan. Jaksa sebagai penyidik mempunyai kewenangan melakukan penyidikan terhadap tindak pidana tertentu seperti tindak pidana korupsi, ini diatur dalam Undang-Undang Nomor 16 Tahun 2004 tentang Kejaksaan Republik Indonesia Pasal 30 ayat (1) d. Di bidang Pidana Kejaksaan mempunyai tugas dan wewenang melakukan penyidikan terhadap tindak pidana tertentu berdasarkan undang-undang.

Jadi apabila terindikasi adanya tindak pidana korupsi di sektor jasa keuangan (sektor perbankan dan lain-lain) maka Jaksa berwenang melakukan penyidikan. Begitu juga penyidik KPK, selaku penyidik mempunyai kewenangan penyidikan terhadap tindak pidana korupsi, seperti diatur dalam Undang-Undang Nomor 30 Tahun 2002 tentang Komisi Pemberantasan Korupsi Pasal 6 c):

Komisi Pemberantasan Korupsi mempunyai tugas : Melakukan penyelidikan, penyidikan dan penuntutan terhadap tindak pidana korupsi.

Dengan demikian penyidik KPK mempunyai kewenangan pula di sektor perbankan dan sektor-sektor otoritas jasa keuangan lainnya, apabila di sektorsektor itu terindikasi adanya tindak pidana korupsi.

Dengan adanya kewenangan penyidikan dari penyidik OJK, maka akan terjadi diverifikasi penyidik dan akan membuat makin tumpang tindihnya penyidikan dalam tindak pidana tertentu yaitu tindak pidana yang diatur di luar KUHAP.

Kasus BLBI yang tak kunjung tuntas, juga kasus Bank Century yang sudah ditangani oleh penyidik KPK, Kepolisian dan Kejaksaan sampai hari ini belum mengakomodir aspirasi masyarakat secara tuntas. Kasus mutakhir tentang tumpang tindihnya penyidikan, adalah dalam kasus/ perkara simulator SIM yang sama-sama ditangani oleh penyidik yaitu penyidik Kepolisian dan Penyidik KPK. 
Akankah penyidik OJK efektif melaksanakan pemberantasan tindak pidana di bidang OJK. Pertanyaan pada awal tulisan ini harus dibuktikan di waktu yang akan datang, sebab kewenangan penyidikannya pun baru akan dijalankan.

\section{Kesimpulan}

1. Untuk melindungi masyarakat terhadap kejahatan jasa keuangan, maka dibuatlah undang-undang tentang jasa keuangan, yaitu Undang-Undang Nomor 21 Tahun 2011. Adapun tugas dan kewenangan OJK adalah antara lain melakukan pengawasan terhadap kegiatan jasa keuangan, selain daripada itu OJK juga mempunyai kewenangan untuk melakukan penindakan terhadap tindak pidana jasa keuangan, yaitu dengan membentuk penyidik tersendiri yaitu penyidik OJK di luar penyidik yang telah ada seperti Penyidik Polisi, Jaksa dan KPK.

2. Dengan lahirnya Undang-Undang Nomor 21 Tahun 2011 tentang Otoritas Jasa Keuangan dimana di dalamnya mengatur tentang penyidik tersendiri, maka dimungkinkan akan terjadi tumpang tindih penyidikan. Baik penyidikan tindak pidana umum maupun tindak pidana khusus. Sebab terhadap tindak pidana yang terjadi dalam Otoritas Jasa Keuangan diatur oleh ketentuan undang-undang yang ada dan telah ada penyidik lain yang berhak melakukan penyidikannya.

Polisi sebagai penyidik tindak pidana - perbankan - diatur dalam Undang-Undang Nomor 8 Tahun 1981 tentang KUHAP Pasal 6 ayat (1) a. Penyidik adalah Polisi Negara Republik Indonesia, selain itu Polisi sebagai penyidik diatur pula dalam Undang-Undang Nomor 2 Tahun 2002 tentang Kepolisian RI Pasal 14 ayat (1) a :

Melaksanakan penyelidikan dan penyidikan terhadap semua tindak pidana sesuai dengan hukum acara pidana dan peraturan perundangundangan lainnya.

Dengan demikian Polisi sebagai penyidik termasuk penyidik mempunyai hak dan kewenangan untuk melakukan penyidikan terhadap semua tindak pidana, termasuk tindak pidana di sektor jasa keuangan (Perbankan dan lain-lain).

Begitu juga Kejaksaan. Jaksa sebagai penyidik mempunyai kewenangan melakukan penyidikan terhadap tindak pidana tertentu seperti tindak pidana korupsi, ini diatur dalam Undang-Undang Nomor 16 Tahun 2004 tentang Kejaksaan Republik Indonesia Pasal 30 ayat (1) d. Di bidang Pidana Kejaksaan mempunyai tugas dan wewenang melakukan penyidikan terhadap tindak pidana tertentu berdasarkan undangundang.

Jadi apabila terindikasi adanya tindak pidana korupsi di sektor jasa keuangan (sektor perbankan dan lain-lain) maka Jaksa berwenang melakukan penyidikan. Begitu juga penyidik KPK, selaku penyidik mempunyai kewenangan penyidikan terhadap tindak pidana korupsi, 
seperti diatur dalam Undang-Undang Nomor 30 Tahun 2002 tentang Komisi Pemberantasan Korupsi Pasal 6 c) :

Komisi Pemberantasan Korupsi mempunyai tugas : Melakukan penyelidikan, penyidikan dan penuntutan terhadap tindak pidana korupsi.

Dengan demikian penyidik KPK mempunyai kewenangan pula di sektor perbankan dan sektor-sektor otoritas jasa keuangan lainnya, apabila di sektor-sektor itu terindikasi adanya tindak pidana korupsi.

3. Tentang efektivitas dari penyidik Otoritas Jasa Keuangan harus dibuktikan di masa yang akan datang. Karena kewenangan yang dipunyai oleh penyidik Otoritas Jasa Keuangan sampai saat ini belum dilaksanakan. Oleh karena itu hasil dan efektivitasnya belum dapat dievaluasi dan diukur. 


\section{Daftar Pustaka}

Adji, Oemar Seno. Hukum (Acara) Pidana dalam Prospeksi, Jakarta: Erangga, 1976.

Arief, Barda Nawawi. Bunga Rampai Kebijakan Hukum Pidana, Cetakan Kesatu, Bandung: Penerbit PT. Citra Aditya Bakti, 1996.

Bonn, E. Sosrodanukusumo. Tunutan Pidana, Djakarta: Penerbit Siliwangi, tanpa tahun.

Hamzah, Andi. Hukum Acara Pidana Indonesia, Jakarta: Sinar Grafika 2006.

Pound, Roscoe. Pengantar Filsafat Hukum, Jakarta: Bharata, 1972.

Prodjodikoro, Wirjono. Hukum Atjara Pidana di Indo, Djakarta: Penerbit Sumur Bandung, 1967.

Saleh, Roelan. Mengadili Sebagai Pergaulan Kemanusiaan, Jakarta: Aksara Baru, 1983.

Sitorus, P. Pengantar Ilmu Hukum (dilengkapi tanya jawab, Pasundan Law Faculty, Bandung: Alumnus Press, 1998.

Soedjono D. Pemeriksaan Pendahuluan Menurut KUHAP. Bandung: Alumni, 1982.

Tahir, Hadari Djenawi. Pokok-Pokok Pikian dalam KUHAP. Bandung: Alumni, 1981.

Tanusuboto, S. Peranan Praperadilan dalam Hukum Acara Pidana. Bandung: Alumni, 1981.

Tresna, R. Komentar HIR. Djakarta: Pradnya Paramita, tanpa tahun.

\section{Undang-Undang}

Undang-Undang Nomor 8 Tahun 1981, tentang Hukum Acara Pidana.

Undang-Undang Nomor 31 Tahun 1999, tentang Pemberantasan Tindak Pidana Korupsi.

Undang-Undang Nomor 21 Tahun 2011, tentang Otoritas Jasa Keuangan. 